\title{
Diagnosis and Recommendation Integrated System (DRIS) approach on Nu- tritional Diagnosis in Fruit crops- A Review
}

\author{
Savita $^{1^{*}}$, Krishnappa $\mathbf{R}^{2}$, Bidyapati Ngangom ${ }^{2}$, M. Thoithoi Devi ${ }^{2}$, Gaurav Mishra ${ }^{3}$, Deepa \\ Rawat $^{1}$ and P. C. Srivastava ${ }^{1}$ \\ ${ }^{1}$ Department of Soil Science, G. B. Pant University of Agriculture and Technology, Pantnagar-263145 \\ (Uttarakhand), INDIA \\ ${ }^{2}$ ICAR Research Complex for NEH Region, Umiam- 793103 (Meghalaya), INDIA \\ ${ }^{3}$ Rain Forest Research Institute, Jorhat-785001 (Assam),INDIA \\ "Corresponding author. E-mail: savitaiihr@gmail .com
}

Received: March 18, 2016; Revised received: August 7, 2016; Accepted: November 22, 2016

\begin{abstract}
Diagnosis and Recommendation Integrated System (DRIS) is widely used statistical approach for interpretation of the plant tissue analysis data and to diagnose the plant nutreint needs much earlier than the reduction of crop yield with greater accuracy. It helps in simultaneous identifying imbalances, deficiencies and excesses of crop nutrients and ranks them in the order of their importance for their remedial steps. The DRIS norms based on foliar composition can developed in any crop and at any stage of its development. It provides a mathematical means of ordering large number of nutrient ratios into nutrient indices that can be easily interpreted. The nutrient ranges been established as deficient, low, optimum, high and excessive based on the mean of nutrient concentration and standard deviation from high yielding population to serve as a guide for a quick and routine diagnostic and advisory purpose. The major advantage of DRIS lies in its ability to minimize the effect of variation in tissue age on diagnosis, which allows a choice of wider range of tissues than permissible under the conventional critical value approach. Thus, DRIS is holistic in nature for identification of nutrient imbalance in crops and formulation of nutrient management strategies for achieving higher yields.
\end{abstract}

Keywords: DRIS indices, DRIS ratio norms, Fruit crops, Nutrient diagnosis

\section{INTRODUCTION}

The perennial fruit crops are distinct from seasonal crops in their nutritional requirement due to their plant size, density, root spread, growth pattern, phenomenon of bud differentiation and their relationship with the yield during the bearing and off-season. Major objectives of proper nutrient management in fruit orchards are to increase the net income through efficient fertilization. This requires a precise determination of the yield-limiting impact of a given nutrient. Determination of the nutritional needs of fruit crops must made prior to determination of potential yield. The best diagnostic tool is the one that recommends nutrients application based on direct economic response of crops. Suitable diagnostic tools were designed to avoid nutrient shortage or excess and with proper usage, there should not be any decrease in fruit production and quality. In additional to this, leaf analysis helps in accurate identification of the need for nutrient fertilization. Leaf analysis, is based on the assumption of positive relationship between the doses of nutrient supplied, leaf nutrient content and the yield. Leaf analysis is useful as it helps to prevent deficiency rather than correcting them after their development. Foliar analy- sis can be a useful tool for assessing plant nutrient status if, adequate procedures are available for diagnosis from the analytical data (Bhargava and Chadha, 1993). The foliar diagnosis is a complex exercise because of the dynamic nature of foliar composition, which has strongly influenced by leaf age and other interactions affecting nutrient uptake and distribution. Among several approaches adopted for interpretation of leaf analysis data, Diagnosis and Recommendation Integrated System (DRIS) is consider the best as it uses nutrient ratios and simultaneously identifies imbalances, deficiencies and excesses in crop nutrients, and, ranks them in the order of importance (Beaufils, 1973). The DRIS norms should be developed for specific conditions, in which all other factors to be correlated with yield or quality (or any other variable) are known: like cultivar, climate, soil and crop management, productivity etc for attaining the specific objectives (Bangroo et al., 2010).

\section{DIAGNOSIS AND RECOMMENDATION INTE- GRATED SYSTEM (DRIS)}

Normally, the concentration of N, P and K in leaves decreases with leaf age, while that of $\mathrm{Ca}$ and $\mathrm{Mg}$ in- 
creases. In order to overcome these problems in nutrient diagnosis the concept of DRIS was introduced. DRIS, developed by Beaufils (1973), is actually a dual ratio concept where mainly, the nutrient concentration ratios are considered rather than single nutrient value and are used for developing leaf/petiole nutrient norms/guides.

The main concept of DRIS envisages that the ratios $\mathrm{N} /$ $\mathrm{P}, \mathrm{N} / \mathrm{K}, \mathrm{P} / \mathrm{K}, \mathrm{Ca} / \mathrm{Mg}$ and their reciprocal should remain constant irrespective of leaf age. The product of NX Ca should be fairly constant. Further, DRIS act as alternative approach by using nutrient ratios rather than concentration themselves to interpret tissue analysis (Beaufils, 1971). DRIS received considerable attention since its introduction as it is described as a comprehensive system, which identifies all the nutritional factors limiting the crop production and helps in increasing the chances of obtaining high yields by improving fertilizer recommendation (Beaufils, 1973). DRIS index values measure how far specific nutrients in the leaf or plant are from optimum range.

Several advantages of this method over the conventional critical level approach have been reported (Walworth and Sumner, 1987) which are follows:

1. Identification of not only the most limiting element, but also the order in which the other elements would likely to become limiting.

2. The ability to diagnose the plant nutrient need to be much earlier in the life span of crop than the critical level approach thus, allowing one to take remedial measures earlier.

3. DRIS provides greater accuracy in diagnosis and offers relatively more freedom from the effect of some of the sampling variables such as the age of the plant part and geographical location etc.

The DRIS approach was designed to provide a valid diagnostic irrespective of plant age, tissue origin (Sumner, 1977, Meldal-Johnsen and Sumner 1980, Bailey et al., 1997, Jones, 1993) cultivar, local conditions (Payne et al., 1990), or changes in the method of tissue sampling or the time of sampling (Moreno et al., 1996). The DRIS is sometimes less sensitive than the sufficiency range approach particularly in terms of differences caused by leaf position, tissue age, climate, soil conditions, and cultivar affect because it uses nutrient ratios (Sanchez et al., 1991). Once DRIS norms have been established and validated from a large population of randomly distributed observations, they should be universally applicable to that crop (Sumner 1977a \& 1979) because for a given species, there has to be specific nutrient ratios for the maximum crop performance that transcend local conditions, such soil, climate and cultivars (Synder and Kretschmer, 1988). Thus, the DRIS had been successfully applied to many fruit crops like grapes (Bhargava and Raghupathi, 1995; Sharma et al., 2005), 'Valencia' orange (Orlando et al., 1997), pomegranate
(Raghupathi and Bhargava, 1998), mango (Hundal et al., 2005), apple (Singh et al., 2000), peach (Awasthi et al., 2000), papaya (Anjaneyulu, 2007), Ber (Kuldip et al.,2010), Aonla (Nayak et al., 2011), Coorgmandarin (Raghupathi et al., 2013) etc. The DRIS norms developed from data banks of observations of a particular cropping system, consisting of minimum tissue nutrient content and associated yields (Sumner, 1990). The norms, which are used as reference standards against which samples to be diagnosed are compared, can be calculated as the means of the various forms expressing the nutrients $(\mathrm{N} / \mathrm{P}, \mathrm{N} / \mathrm{K}$, and $\mathrm{K} / \mathrm{P}$ etc.) for high yielding population of plants. The DRIS indices measure the deviations of various forms of expressions in the tissue under diagnosis from their respective norm values.

DRIS norm development: The first step in implementing DRIS is the establishment of standard values or norms. The DRIS utilizes a survey approach (Beaufils, 1973) for norms determination based on crop response model (Sumner and Farina, 1986). In DRIS, the populations of observations are divided into two subgroups viz low and high yielding groups based on cut-off yield and then mean values of high yielding groups that taken as estimates of tissue parameter optima. In addition, the coefficient of variation of high yielding data provides a measure of the relative spread or breadth of the yield response surface at upper yield levels (Walworth and Sumner, 1987).

The actual cut-off value used to divide low and high yield groups is not critical as long as the high yield data remain normally distributed (Fig. 1). In corn, when the cut-off value for dividing high and low corn yields varied from 7 to $9 \mathrm{Mg} \mathrm{ha}^{-1}$ than the normal value for average tissue $\mathrm{N} / \mathrm{P}, \mathrm{N} / \mathrm{K}$, and $\mathrm{P} / \mathrm{K}$ ratios which varied 6.7, 4.8 and 2.4 per cent, respectively (Letzsch and Sumner, 1984). In practice, the chosen cut-off values are usually represented yields that farmers routinely obtain. For each pair of nutrients, there are three forms of expression that may be considered. For example, $\mathrm{N}$ and $\mathrm{P}$ can related as ratio of $\mathrm{N} / \mathrm{P}$, its inverse $\mathrm{P} / \mathrm{N}$ or product $\mathrm{N} \times \mathrm{P}$. In DRIS calculation, only one expression is used to relate each nutrient pair. The selection of is done by comparing the variation of low yielding group to that of high yielding segment of the population. The form of expression (N/P, P/N or $\mathrm{N} \times \mathrm{P})$ selected for the use in DRIS computation is the one associated with the largest variance ratio and lower coefficient variation (Fig. 2) (Beaufils, 1973 and Walworth and Sumner, 1987).

DRIS index/ indices and interpretations: DRIS provides a means of ordering nutrient ratios into meaningful expressions in the form of indices. The actual nutrient imbalance in plant is diagnosed through DRIS indices. Total sum of DRIS indices is zero. The DRIS indices were calculated as described by Walworth and Sumner (1987) by using the fol- 
Savita et al. / J. Appl. \& Nat. Sci. 8 (4): 2337-2345 (2016)

\begin{tabular}{cc}
\hline Index $\mathrm{A}=$ & $\frac{[f(\mathrm{~A} / \mathrm{B})+f(\mathrm{~A} / \mathrm{C})+f(\mathrm{~A} / \mathrm{D}) \ldots+f(\mathrm{~A} / \mathrm{N})]}{\mathrm{Z}}$ \\
\hline $\operatorname{Index~} \mathrm{B}=\frac{[-f(\mathrm{~A} / \mathrm{B})+f(\mathrm{~B} / \mathrm{C})+f(\mathrm{~B} / \mathrm{D}) \ldots+f(\mathrm{~B} / \mathrm{N})]}{\mathrm{Z}}$ \\
$\operatorname{Index~} \mathrm{N}=\frac{[-f(\mathrm{~A} / \mathrm{N})+f(\mathrm{~B} / \mathrm{N})-f(\mathrm{C} / \mathrm{N}) \ldots+f(\mathrm{M} / \mathrm{N})]}{\mathrm{Z}}$ \\
\hline
\end{tabular}

lowing formula, as an example for one nutrient as

\begin{tabular}{lllll}
\hline$f(\mathrm{~A} / \mathrm{B})=$ & $\frac{(\mathrm{A} / \mathrm{B}-1)}{\mathrm{a} / \mathrm{b}}$ & & $\mathrm{X}$ & $\frac{1000}{\mathrm{CV}}$ \\
\hline given below & & & \\
\hline$f(\mathrm{~A} / \mathrm{B})=$ & $\frac{(1-\mathrm{A} / \mathrm{B})}{\mathrm{a} / \mathrm{b}}$ & & $\times$ & $\frac{\mathrm{CV}}{1000}$ \\
\hline
\end{tabular}

Where, when $\mathrm{A} / \mathrm{B}$ is larger or equal to $\mathrm{a} / \mathrm{b}$, when $\mathrm{A} / \mathrm{B}$ is smaller than $\mathrm{a} / \mathrm{b}$,

In these equations, $\mathrm{A} / \mathrm{B}$ is designated the tissue nutrient ratio of the plant to be diagnosed, $a / b$ is the optimum value or norm for given ratio; $\mathrm{CV}$ is the coefficient of variation associated with the norm; and $\mathrm{Z}$ is the number of functions in the nutrient index composition. Values for other functions, such as $f(\mathrm{~A} / \mathrm{C})$ and $f$ $(\mathrm{A} / \mathrm{D})$, are also calculated in the same way using appropriate norms and $\mathrm{CV}$. In other words, one nutrient index is the average function of all the ratios containing a given nutrient. The components of this average value are weighted by the reciprocal of the CVs of the high-yielding populations (reference populations). Thus, if the $\mathrm{A} / \mathrm{B}$ and $\mathrm{A} / \mathrm{C}$ ratios are both used to generate an index for the A nutrient and the contribution of each one to the calculation of this index will be function of the $\mathrm{CV}$ values (reference ratios) associated with them, which will reflect the relative influence of these two expressions in the fruit yield. It is important to remember that the composition of the formulae will depend on the situation and there is no fixed formula to use under all crops/situations. The investigator can attempt to work out the formulae for a given crop and use it. In a plant sample with optimal nutrient balance, all nutrient indices would equal to zero. However, it is important to recognize that an individual nutrient is not necessarily present in optimum concentration even if its index equals zero (Walworth and Sumner, 1987). For instance, if the results of a diagnosis were as follows:

$\begin{array}{lccccc}\text { Nutrient } & \mathrm{N} & \mathrm{P} & \mathrm{K} & \mathrm{Ca} & \mathrm{Mg} \\ \text { Index } & -14 & 0 & +4 & +4 & +6\end{array}$

Among the nutrients tested, $\mathrm{N}$ had the most negative index and was likely to be yield limiting. Although the $\mathrm{P}$ index equaled zero, it was relatively less abundant than $\mathrm{K}$ and $\mathrm{Ca}$ or $\mathrm{Mg}$ and was the second most needed or limited nutrient in the diagnosis. Potassium, $\mathrm{Ca}$ and $\mathrm{Mg}$ levels were excessive relative to $\mathrm{N}$ and $\mathrm{P}$. However, the recommendation from the above diagnosis index is supplementation of both the deficient $\mathrm{N}$ and to a lesser extent the $\mathrm{P}$ also ( $\mathrm{P}$ index is zero) (Walworth and Sumner, 1987). Total nutrient balance in a plant may be indicated by the sum of the nutrient indices irrespective of the sign, which is called as Nutrient Balance Index (NBI). When the sums of the DRIS indices are large, one or more of the measured factors may limits the yield. Such relationship established between NBI and fruit yield of pineapple (Fig. 3). Moreover higher yields can result only when sum of indices are small, although high yields may still occur if other factors are limiting (Beaufils, 1973, Walworth and Sumner, 1987; Mourao- Filho, 2004).

Leaf nutrient ranges/standards: Bhargava and Chadha, (1993) developed five leaf/petiole nutrient ranges/standards which have been derived using mean and standard deviation as deficient, low, optimum, high and excess for each nutrient. The optimum nutrient ranges are the value derived from 'mean - 4/3 SD to mean $+4 / 3$ SD'. The range 'low' was obtained by calculating 'mean $-4 / 3$ SD to mean $-8 / 3$ SD' and the value below 'mean $-8 / 3$ SD' was considered as deficient. The value from 'mean $+4 / 3$ SD to mean $+8 / 3$ SD' was taken as high and the value above 'mean + 8/3 SD' was taken as excessive. Using these leaf nutrients range formulae developed into petiole nutrient ranges for Thompson seedless Grapes (Vitis vinifera) as deficient, low, optimum, high and excess as represented in Table 1 (Bhargava, 2002).

Specific application of DRIS method in fruit

Table 1. Petiole nutrient ranges for Thompson seedless grapes.

\begin{tabular}{|c|c|c|c|c|c|c|}
\hline Element & Unit & Deficient & Low & Optimum/sufficient & High & Excess \\
\hline $\mathrm{N}$ & $\%$ & $<0.62$ & $0.62-0.90$ & $0.91-1.44$ & $1.45-1.73$ & $>1.73$ \\
\hline $\mathrm{P}$ & $\%$ & $<0.07$ & $0.07-0.11$ & $0.12-0.28$ & $0.29-0.38$ & $>0.38$ \\
\hline $\mathrm{K}$ & $\%$ & $<1.20$ & $1.20-2.21$ & $2.22-3.37$ & $3.38-5.03$ & $>5.03$ \\
\hline $\mathrm{Ca}$ & $\%$ & $<1.37$ & $1.37-2.64$ & $2.65-4.19$ & $4.20-5.55$ & $>5.55$ \\
\hline $\mathrm{Mg}$ & $\%$ & $<0.32$ & $0.32-0.66$ & $0.67-1.37$ & $1.38-1.74$ & $>1.74$ \\
\hline $\mathrm{S}$ & $\%$ & $<0.08$ & $0.08-0.17$ & $0.18-0.37$ & $0.38-0.48$ & $>0.48$ \\
\hline $\mathrm{Fe}$ & $\mu \mathrm{g} \mathrm{g}^{-1}$ & $<24$ & $24-32$ & $33-92$ & $93-124$ & $>124$ \\
\hline $\mathrm{Mn}$ & $\mu \mathrm{g} \mathrm{g}^{-1}$ & $<21$ & $21-33$ & $34-60$ & $61-74$ & $>74$ \\
\hline $\mathrm{Zn}$ & $\mu \mathrm{g} \mathrm{g}^{-1}$ & $<10$ & $10-16$ & $17-40$ & $41-54$ & $>54$ \\
\hline $\mathrm{Cu}$ & $\mu \mathrm{g} \mathrm{g}^{-1}$ & $<2$ & $2-5$ & $6-12$ & $13-17$ & $>17$ \\
\hline Yield & $\left(\mathrm{t} \mathrm{ha}^{-1}\right)$ & $<23.16$ & $23.2-26.6$ & 26.61.33.82 & $33.83-37.37$ & $>38.00$ \\
\hline
\end{tabular}

(Source: Bhargava, 2002) 
Table 2. DRIS norms and critical nutrient levels in the $3^{\text {rd }}$ lamina of banana established from published sources.

\begin{tabular}{cccc}
\hline Nutrient expression (\%) & DRIS & Critical value range & Av. of published critical values \\
\hline Nitrogen & 3.04 & $1.81-4.00$ & 3.03 \\
Phosphorus & 0.23 & $0.12-0.41$ & 0.22 \\
Potassium & 4.49 & $1.66-5.40$ & 3.40 \\
\hline
\end{tabular}

(Source: Angeles et al., 1993)

Table 3. Leaf nutrient composition and DRIS indices in aonla plants.

\begin{tabular}{|c|c|c|c|c|c|c|c|c|c|c|}
\hline \multirow{2}{*}{$\begin{array}{c}\text { Age of } \\
\text { plant } \\
\text { (Years) }\end{array}$} & \multirow{2}{*}{$\begin{array}{c}\text { Yield } \\
(\mathbf{k g} \\
\left.\mathrm{ha}^{-1}\right)\end{array}$} & \multicolumn{4}{|c|}{ Leaf nutrient composition } & \multicolumn{4}{|c|}{ DRIS indices } & \multirow{2}{*}{$\begin{array}{c}\text { Requirement } \\
\text { order }\end{array}$} \\
\hline & & $\begin{array}{c}\mathrm{N} \\
(\%)\end{array}$ & $P(\%)$ & $\begin{array}{c}\mathrm{K} \\
(\%)\end{array}$ & $\underset{\left(\mu g^{-1}\right)}{Z n}$ & $\mathbf{N}$ & $\mathbf{P}$ & $\mathbf{K}$ & $\mathbf{Z n}$ & \\
\hline 5 & 29.8 & 1.87 & 0.10 & 0.68 & 48.9 & -924 & 1569 & 49 & -695 & $\mathrm{~N}>\mathrm{Zn}>\mathrm{K}>\mathrm{P}$ \\
\hline 10 & 34.6 & 1.84 & 0.089 & 0.798 & 50.2 & -1491 & -564 & 2479 & -424 & $\mathrm{~N}>\mathrm{P}>\mathrm{Zn}>\mathrm{K}$ \\
\hline 15 & 40.2 & 1.50 & 0.079 & 0.582 & 67.8 & -5197 & -1713 & -1652 & 8562 & $\mathrm{~N}>\mathrm{P}>\mathrm{K}>\mathrm{Zn}$ \\
\hline 20 & 30.0 & 1.47 & 0.070 & 0.527 & 45.4 & -1249 & -704 & -413 & 2365 & $\mathrm{~N}>\mathrm{P}>\mathrm{K}>\mathrm{Zn}$ \\
\hline$>20$ & 28.3 & 1.34 & 0.079 & 0.692 & 36.5 & -3719 & 1508 & 4463 & -2252 & $\mathrm{~N}>\mathrm{P}>\mathrm{K}>\mathrm{Zn}$ \\
\hline
\end{tabular}

(Source: Nayak et al., 2011)

Table 4. Mean, range of nutrient concentrations in papaya and DRIS ratios norms for papaya.

\begin{tabular}{cccccccc}
\hline Nutrient & Unit & Mean & Range & Selected ratio & Norms & Selected ratio & Norms \\
\hline $\mathrm{N}$ & $\%$ & 1.18 & $0.85-1.65$ & $\mathrm{~N} / \mathrm{P}$ & 6.368 & $\mathrm{P} / \mathrm{Zn}$ & 0.008 \\
$\mathrm{P}$ & $\%$ & 0.21 & $0.08-0.38$ & $\mathrm{~N} / \mathrm{K}$ & 0.571 & $\mathrm{Cu} / \mathrm{P}$ & 48.21 \\
$\mathrm{~K}$ & $\%$ & 2.48 & $1.00-4.45$ & $\mathrm{Ca} / \mathrm{N}$ & 2.553 & $\mathrm{Ca} / \mathrm{K}$ & 1.500 \\
$\mathrm{Ca}$ & $\%$ & 2.92 & $1.16-4.72$ & $\mathrm{Mg} / \mathrm{N}$ & 0.899 & $\mathrm{Mg} / \mathrm{K}$ & 0.498 \\
$\mathrm{Mg}$ & $\%$ & 1.03 & $0.55-1.99$ & $\mathrm{~S} / \mathrm{N}$ & 0.243 & $\mathrm{~S} / \mathrm{K}$ & 0.137 \\
$\mathrm{~S}$ & $\%$ & 0.28 & $0.14-0.45$ & $\mathrm{Fe} / \mathrm{Mn}$ & 55.80 & $\mathrm{Fe} / \mathrm{K}$ & 31.29 \\
$\mathrm{Fe}$ & $\mu \mathrm{gg} \mathrm{g}^{-1}$ & 64 & $31-139$ & $\mathrm{~N} / \mathrm{Mn}$ & 0.025 & $\mathrm{Mn} / \mathrm{K}$ & 23.25 \\
$\mathrm{Mn}$ & $\mu \mathrm{gg}^{-1}$ & 48 & $30-76$ & $\mathrm{~N} / \mathrm{Zn}$ & 0.045 & $\mathrm{~K} / \mathrm{Zn}$ & 0.093 \\
$\mathrm{Zn}$ & $\mu \mathrm{gg}^{-1}$ & 29 & $8-56$ & $\mathrm{~N} / \mathrm{Ca}$ & 0.138 & $\mathrm{Cu} / \mathrm{K}$ & 4.280 \\
$\mathrm{Cu}$ & $\mu \mathrm{gg} \mathrm{g}^{-1}$ & 09 & $6-22$ & $\mathrm{P} / \mathrm{K}$ & 0.026 & $\mathrm{Ca} / \mathrm{Mg}$ & 2.980 \\
\hline
\end{tabular}

(Source: Anjaneyulu, 2007)

crops: In Vacaria, Brazil, Nachtigall and Dechen (2007) also evaluated the nutritional status of apple (Malus domestica) using the DRIS method. The DRIS indices and NBI for each nutrient were determined using three methods viz. Beaufils, Jones, and Elwali and Gascho. Results from their research showed that (i) the NBI, calculated from the generated norms, were negatively correlated with productivity and fruit coloration, and (ii) the DRIS method, described by Elwali and Gascho and using the F value, was the most suitable for apple tree orchards, because the NBI values obtained with this method best indicated the nutritional status of the plants and provided a more accurate nutritional diagnosis.

Angeles et al. (1993) developed DRIS norms for banana (Musa spp.) using 915 observations from 26 sources. The reference subpopulation was selected based on productivity of equal or higher than $70 \mathrm{t} \mathrm{ha}^{-1}$. The indices originated from the developed norms were compared with the method of critical values and results of both methods were similar, except for $\mathrm{K}$ and $\mathrm{K} /$ nutrient ratios (Table 2). The DRIS norms validity and their advantages over the method of critical values for providing correct nutritional diagnosis were partially confirmed through a fertilization experiment. In Eastern Africa, the experiments carried out in 45 farms in the region of Kagera, Tanzania, also derived new norms to estimate the nutritional status of the banana plantation, using both DRIS and the critical value method (Wortmann et al., 1994).

Hundal et al. (2005) carried out DRIS studies on mango (Mangifera indica. L) trees in Punjab, India. Standard norms established from the nutrient survey of mango orchards were $1.144 \% \mathrm{~N}, 0.126 \% \mathrm{P}, 0.327 \% \mathrm{~K}$, $2.587 \% \mathrm{Ca}, 0.263 \% \mathrm{Mg}, 0.141 \% \mathrm{~S}$ and $15 \mathrm{mg} \mathrm{Zn,} 3.5$ $\mathrm{mg} \mathrm{Cu}, 145 \mathrm{mg} \mathrm{Fe}, 155 \mathrm{mg} \mathrm{Mn}$ and $30 \mathrm{mg} \mathrm{B} \mathrm{kg}^{-1}$ dry matter. Based on DRIS indices, 16, 15, 12, 17, and $16 \%$ of total samples collected during nutrients survey 
Savita et al. / J. Appl. \& Nat. Sci. 8 (4): 2337-2345 (2016)

Table 5. Nutrient diagnosis norms for pomegranate with different techniques of interpretation.

\begin{tabular}{ccccc}
\hline Nutrients & Unit & CVA & DRIS & CND \\
\hline $\mathrm{N}$ & $\%$ & 1.46 & 1.59 & 0.17 \\
$\mathrm{P}$ & $\%$ & 0.18 & 1.17 & 0.18 \\
$\mathrm{~K}$ & $\%$ & 1.19 & 1.81 & 1.09 \\
$\mathrm{Ca}$ & $\%$ & 2.35 & 0.30 & 1.33 \\
$\mathrm{Mg}$ & $\%$ & 0.40 & 0.30 & 0.37 \\
$\mathrm{~S}$ & $\%$ & 0.40 & 105 & 0.37 \\
$\mathrm{Fe}$ & $\mu \mathrm{g} \mathrm{g}^{-1}$ & 114 & 47 & 91 \\
$\mathrm{Mn}$ & $\mu \mathrm{g} \mathrm{g}^{-1}$ & 53 & 47 & 44 \\
$\mathrm{Zn}$ & $\mu \mathrm{gg}^{-1}$ & 16 & 35 \\
\hline
\end{tabular}

(Source: Raghupathi and Bhargava, 1999).

of mango orchards were low in $\mathrm{N}, \mathrm{P}, \mathrm{K}, \mathrm{Ca}$, and $\mathrm{Mg}$, respectively. For micronutrients, 19, 18, 12, 20, and $6 \%$ samples were inadequate in $\mathrm{Zn}, \mathrm{Cu}, \mathrm{Fe}, \mathrm{Mn}$ and $\mathrm{B}$, respectively. Sharma et al. (2005) used data bank of nutrient concentration and yield for vines grafted on dog-ridge rootstock (Vitischampini) for developing DRIS ratio norms during bud differentiation and flowering stage. Sixty-six nutrient expressions were chosen as diagnostic norms. Among the nutrient ratios selected to form diagnostic parameters, $\mathrm{P} / \mathrm{N}(0.260), \mathrm{K} / \mathrm{N}$ (1.761) $\mathrm{P} / \mathrm{Zn}(0.0056)$ had greater physiological rationale during flowering stage. While, N/P (3.42) and N/K (0.68) were more critical during bud differentiation stage. Sodium followed by $\mathrm{Mg}, \mathrm{Ca}, \mathrm{Fe}, \mathrm{Cu}$ and $\mathrm{K}$ were the most common yield limiting nutrients whereas, $\mathrm{K}$, $\mathrm{Mn}$ and $\mathrm{Fe}$ at bud differentiation stage and $\mathrm{Ca}, \mathrm{N}$, and $\mathrm{Mg}$ at flowering stage were considered as excessive.

Raghupathi and Bhargava (1998) developed leaf nutrient diagnostic norms for pomegranate (Punica granatum L.) grown in Bijapur district of Northern Karnataka, India, found the optimum ranges of nutrients in leaf varying from 0.91 to $1.66 \% \mathrm{~N}, 0.12$ to $0.18 \% \mathrm{P}$ and 0.61 to $1.59 \% \mathrm{~K}$. The evaluation of the individual low yielding orchards of pomegranate indicated that low levels of soil $\mathrm{Zn}$ and $\mathrm{Cu}$ were responsible for the low yields. Awasthi et al. (2000) developed DRIS norms for peach (Prunus persica L cv. July El-

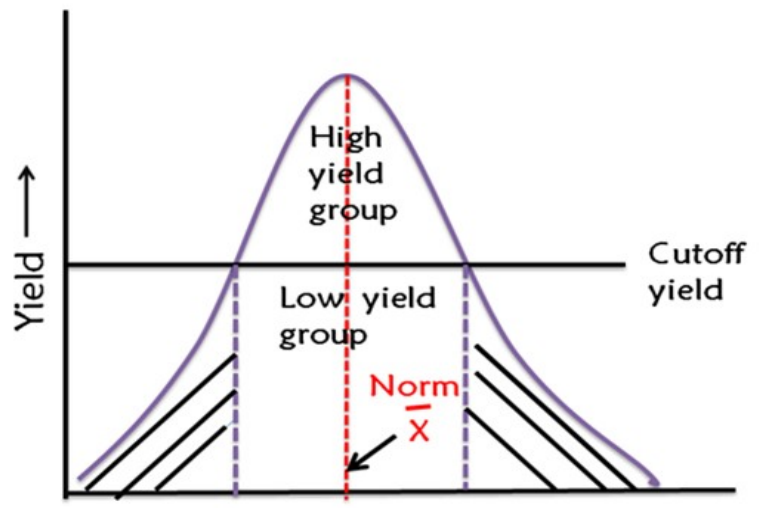

Nutrient Expression

Fig. 1. Schematic illustration of DRIS norms. (Source: Walworth and Sumner, 1987). berta) in Rajgarh, Himachal Pradesh, India from the data base of 1,200 observations, using DRIS approach revealed that DRIS indices for $\mathrm{N}, \mathrm{P}, \mathrm{K}, \mathrm{Ca}$, and $\mathrm{Mg}$ varied from -58 to $-1,-66$ to 8,15 to 89,305 to 577 and -314 to -601 , respectively. The order of requirement in $60 \%$ peach orchards was $\mathrm{Mg}>\mathrm{N}>\mathrm{P}>\mathrm{K}>\mathrm{Ca}$ and remaining $40 \%$ was in the order of requirement, $\mathrm{Mg}>\mathrm{P}>\mathrm{N}>\mathrm{K}>\mathrm{Ca}$. In addition the study revealed that $\mathrm{Mg}$ was the most yield-limiting nutrient in peach orchards of Himachal Pradesh, followed by $\mathrm{N}$ and $\mathrm{P}$. The $\mathrm{Ca}$ and $\mathrm{K}$ application were least required in these orchards.

The DRIS norms recognized from N, P, K, and Zn composition of aonla (Emblica officinalis) leaf samples were further employed to compute DRIS indices in orchards of Uttar Pradesh by Nayak et al. (2011). Specified nutrient requirements as per DRIS indices were in the order of $\mathrm{N}>\mathrm{P}>\mathrm{K}>\mathrm{Zn}$ in most groups of plants. Nitrogen is the most limiting element in all age group of plant (Table 3). When compared age-wise among orchards, a relative deficiency for $\mathrm{N}, \mathrm{P}$, and $\mathrm{K}$ corresponding to relative sufficiency for $\mathrm{Zn}$ was detected by the DRIS technique for the plants above the age group of 15 years onwards. In younger orchards $(5$ years old), a relative deficiency of $\mathrm{N}, \mathrm{Zn}$, and $\mathrm{K}$ and a relative sufficiency of $\mathrm{P}$ was detected. Anjaneyulu (2007) has conducted studies using DRIS on papaya (Carica papaya) for development of petiole nutrient norms. A total of three hundred samples were collected
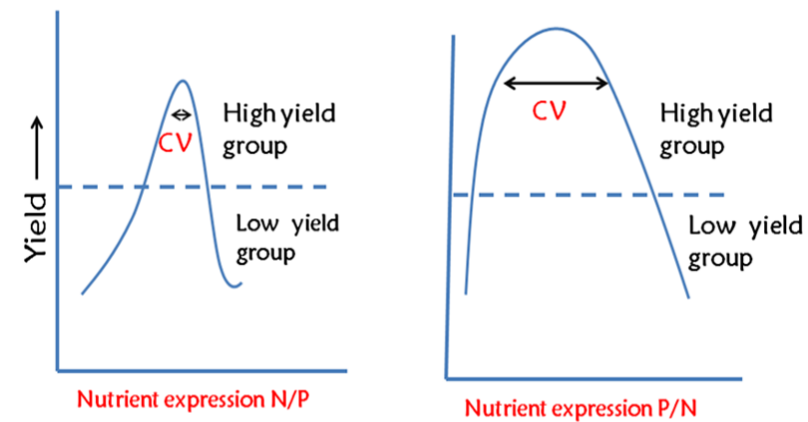

Fig. 2. Schematic representations of relationship between nutrient expressions and yield. (Source: Walworth and Sumner, 1987). 


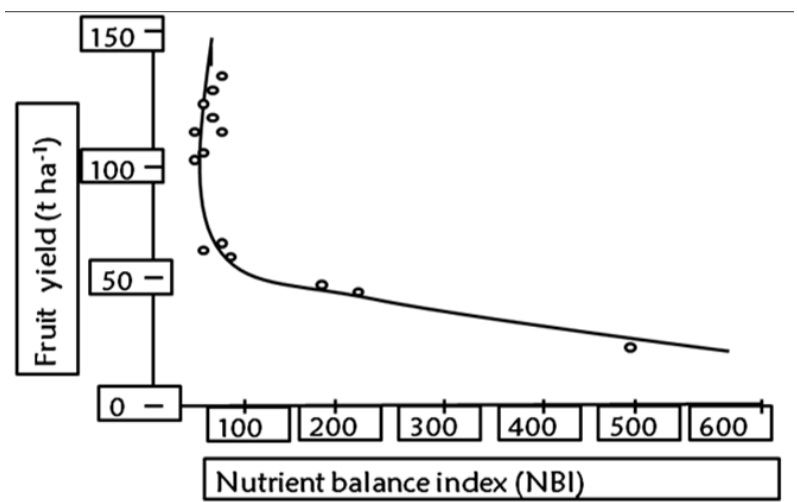

Fig. 3. Relationship between nutrient balance index (NBI) and fruit yield of pineapple (Source-Angles et al. 1990).

and analyzed for macro- and micro-nutrients for the data bank and forty-five nutrient expressions were selected as diagnostic norms (Table 4) viz., N/P (6.368), $\mathrm{N} / \mathrm{K}$ (0.571), $\mathrm{Mg} / \mathrm{N}$ (0.899), N/Zn (0.045), Ca/Mn (0.062), $\mathrm{Ca} / \mathrm{Zn}$ (0.0115), $\mathrm{Mg} / \mathrm{Zn}(0.039)$ and $\mathrm{S} / \mathrm{Zn}$ $(0.010)$ etc. The diagnosis of nutrient imbalance through DRIS indices indicated that the most common yield-limiting nutrient was $\mathrm{Zn}$ followed by K. The optimum nutrient concentrations ranged from 0.91 to $1.44 \% \mathrm{~N}, 0.12$ to $0.28 \% \mathrm{P}, 2.22$ to $3.75 \% \mathrm{~K}, 2.65$ to $4.19 \% \mathrm{Ca}, 0.67$ to $1.37 \% \mathrm{Mg}$ and 0.18 to $0.37 \% \mathrm{~S}$. Among the micronutrients, the optimum ranges varied from 17 to $40 \mathrm{mg} \mathrm{Zn,} 33$ to $92 \mathrm{mg} \mathrm{Fe}, 34$ to $60 \mathrm{mg} \mathrm{Mn}$ and 6 to $12 \mathrm{Cu} \mathrm{mg} \mathrm{kg}{ }^{-1}$ tissues (Table 4). Anjaneyulu (2008) developed the DRIS norms for guava (Psidium guajava). Among the nutrient expressions selected as diagnostic norms, some expression such as $\mathrm{P} / \mathrm{N}$ (0.105), N/K (1.375), P/Mg (0.485), P/Zn (0.006), K/ $\mathrm{Zn}(0.042), \mathrm{Mg} / \mathrm{K} \quad(0.302), \quad \mathrm{Mg} / \mathrm{S} \quad(1.147), \mathrm{Fe} / \mathrm{Zn}$ (4.302) etc. had greater physiological rationale, as they showed lower coefficient of variation compared to other ratios. The DRIS indices indicated that $\mathrm{Zn}$ followed by $\mathrm{K}$ were the most common yield limiting nutrients in guava.

Raghupathi et al. (2013) surveyed Coorg mandarin (Citrus reticulate) in Kodagu region of Karnataka, India to develop data bank of nutrient concentration and yield. Twenty-eight nutrient expressions were derived for identification of nutrient imbalance in Coorg mandarin. Among the nutrient expressions selected as diagnostic norms, some expressions such as N/P (6.427), N/K (1.703) and $\mathrm{P} / \mathrm{Zn}$ (0.0134) were found to have greater physiological rationale in seedling plants. The ratio of N/P (7.17), N/K (1.395) and $\mathrm{Zn} / \mathrm{P}$ (77.80) and $\mathrm{Ca} / \mathrm{Mg}$ (5.92) were found important in budded plants. DRIS identified $\mathrm{Zn}$ and $\mathrm{Mg}$ as the most yieldlimiting nutrients in Coorg mandarin. MouraoFilho and Azevedo (2003) established DRIS norms for the 'Valencia' sweet orange (Citrus sinensis L.) budded on Rangpur lime, Caipira sweet orange and Poncirus trifoliate rootstocks. The nutritional balance indexes cal- culated by the derived norms were highly correlated with yield for the rootstock/scion combinations. They inferred that DRIS norms might be for leaves sampled from non-bearing fruit branches of irrigated-plant groves. Nutrient sufficiency ranges derived from DRIS norms were $0.688-1.648 \% \mathrm{~N}, 0.184-0.339 \% \mathrm{P}, 1.178$ $-1.855 \% \mathrm{~K}, 1.064-1.768 \% \mathrm{Ca}, 0.234-0.391 \% \mathrm{Mg}$, 0.124-0.180\% S, 55-205 mg Fe, 26-80 mg Mn, 17-33 $\mathrm{mg} \mathrm{Zn}$, and 5-11 $\mathrm{mg} \mathrm{Cu} \mathrm{kg}^{-1}$ using DRIS norms in ber (Zizyphus mauritiana) (Kuldip et al. 2011).

Savita and Anjaneyulu (2008) surveyed 106 orchards growing sapota (Manilkara zapota cv. Kalipatti) in Northern Karnataka, India for developing leaf nutrient norms using DRIS showed that $\mathrm{K}, \mathrm{B}$ and $\mathrm{Zn}$ were the most common yield-limiting nutrients. Optimum leaf nutrient content ranged from 1.51 to $2.09 \% \mathrm{~N}, 0.06$ to $0.15 \% \mathrm{P}, 0.83$ to $1.44 \% \mathrm{~K}, 1.36$ to $2.34 \% \mathrm{Ca}, 0.54$ to $0.68 \% \mathrm{Mg}$ and 0.48 to $0.80 \% \mathrm{~S}$. Among the micronutrients, optimum concentrations ranged from 109 to $206 \mathrm{mg} \mathrm{Fe}, 49$ to $99 \mathrm{mg} \mathrm{Mn}, 13.3$ to $21.9 \mathrm{mg} \mathrm{Zn,} 3.76$ to $9.10 \mathrm{mg} \mathrm{Cu}$ and 34.8 to $66.8 \mathrm{mg} \mathrm{B} \mathrm{kg}^{-1}$. Hundal and Arora, (1996) used DRIS for foliar diagnosis of micronutrients in litchi (Litchi chinensis Sonn.). They concluded that DRIS norms can be used irrespective of variety and position of leaf sampled from the floral or non-floral panicleswith inadequacy levels for $\mathrm{Zn}, \mathrm{Cu}$, $\mathrm{Fe}$ and $\mathrm{Mn}$ are 14, 10, 190 and $20 \mathrm{mg} \mathrm{kg}^{-1}$ leaf tissues, respectively. Further, Disha et al. (2012) carried out a survey on leaf sampling in plum (Prunus domestica ssp. Domestica cv. Santa Rosa) orchards of Kullu district of Himachal Pradesh, India. Their study revealed the deficiency of $\mathrm{N}, \mathrm{P}, \mathrm{K}, \mathrm{Mg}, \mathrm{Zn}, \mathrm{Mn}$ and $\mathrm{B}$ were diagnosed in $4,12,20,12,24,8$ and $32 \%$ orchards, respectively, while an excess of $\mathrm{N}, \mathrm{Fe}$ and $\mathrm{Cu}$ were diagnosed in 8,36 and $12 \%$ orchards respectively. The order of nutrients limiting in different orchards indicated that $\mathrm{B}$ was the most limiting nutrient as $32 \%$ orchards showed its deficiency, while $24 \%$ orchards showed Zn deficiency.

\section{A COMPARISON OF DRIS AND OTHER DIAG- NOSTIC SYSTEMS}

Sumner (1979) critically evaluated the precision and flexibility of different foliar diagnostic techniques in making a valid diagnosis of nutrient imbalances in crops. A comparison of diagnostic precision between critical level and DRIS approach was made using data from various field crop experiments with corn, soybean sugarcane, and potatoes and it was opined that DRIS was superior to critical value approach. In most comparisons of diagnostic capabilities of critical value or sufficiency range systems and DRIS, the tissue sampling had been done at a specific stage of growth. Even under these conditions, DRIS usually maintains slightly a higher diagnostic precision. According to Sumner (1979), the DRIS based treatment resulted in 39 successes with 12 failures whereas, treatment based 
on critical values resulted in 22 successes with 11 failures in the case of potato crop. Similarly, in corn 166 successes and 24 failures were recorded with DRIS, whereas these were 133 successes and 34 failures with critical value systems (Walworth and Sumner, 1987). Research works carried out in Hungary investigated on the DRIS standard ratios for apple (Malus domestica Borkh) orchards (Szucs et al., 1990). The data on yield and leaf nutrient concentration from 18 representative orchards were collected during three consecutive years. With the conventional DRIS method based calculations, the indices indicated $\mathrm{K}$-excess and $\mathrm{P}$ deficiency, while the $\mathrm{N}$ concentrations were adequate. The norms estimated by quadratic regression analyses for $\mathrm{N} / \mathrm{P}, \mathrm{N} / \mathrm{K}$ and $\mathrm{K} / \mathrm{P}$ indicated $\mathrm{K}$ excess and relative $\mathrm{N}$ - and $\mathrm{P}$-deficiency. It was concluded that the norms obtained by regression analysis might possibly point out more extreme nutrient ratios than the traditional method.

Wairegi and Van-Asten (2011) compared the norms for banana (Musa spp. AAA) using CND, DRIS and a DRIS that includes a filling value (DRIS-Rd) in East African highland. The data on foliar N, P, K, Ca and $\mathrm{Mg}$ concentrations and plant performance were obtained from 300 plots in Uganda. CND indices were closely related to DRIS and DRIS-Rd indices $\left(\mathrm{R}^{2}>0.965\right)$. Four nutrient interactions were common in both low and high bunch weight sub-populations. Although the three approaches could be used to diagnose nutrient imbalances in AAA- bananas, the CND was recommended because of the ease in use.

Raghupathi and Bhargava (1999) compared the diagnostic norms using univariable critical value approach (CVA), bivariate DRIS and CND in 112 selected commercial orchards of pomegranate (Punicagranatum cv. Ganesh) in India. Among CVA, DRIS and CND, the differences in the norm values were also noticed for $\mathrm{N}, \mathrm{Ca}, \mathrm{Fe}$ and $\mathrm{Zn}$. The norms values and identification of yield limiting nutrients were close to each other with DRIS and CND, while there was no consensus with CVA norms and the diagnosis. When several nutrients are likely to limit yield simultaneously, the diagnosis of mineral disorder by multivariate CND approach is better for higher diagnostic precision (Table 5). Therefore, CND approach provides a better theoretical basis for further improvement in foliar diagnosis as compared to CVA and DRIS (Raghupathi and Bhargava, 1999).Santos (1997) evaluated the DRIS method using results of leaf analysis derived from a series of field experiments with $\mathrm{N}, \mathrm{P}$ and $\mathrm{K}$ fertilization in commercial citrus groves of the São Paulo State. He obtained superior results with the DRIS for detecting yield limitation by nutrient deficiency as compared to the SRA. Among the three available procedures for the DRIS indices calculations, the one proposed by Jones (1981) was found to be the most advantageous.
Creste (1996) reported that the first DRIS evaluation by comparison with the sufficiency range approach (SRA) in 'Siciliano' lemon (Citrus limonium) groves of Brazil. The data was obtained from the analysis of leaves of fruiting branches of different plant ages and rootstocks in several harvesting years. The reference population was derived from plants with productivity greater than $80 \mathrm{t} \mathrm{ha}^{-1}$. After the DRIS norms calculations, the method was evaluated under field conditions. The DRIS was shown to be more advantageous over the SRA, as it was able to mainly discriminate the nutrient importance in the order of their deficiency or excess. The diagnosis of nutritional status of bananas (Musa spp.) through plant analysis not only provided the basis of correct fertilizer requirement of the crop but also guided towards the nutritional requirements of the future crops. The DRIS is also used for interpreting plant analysis data, based on a comparison of calculated elemental ratio indices with established norms. The plant analysis with standardized scores (PASS), the most efficient diagnosis systems, has not been effectively utilized for bananas. The accurate plant sampling, handling, and analysis of the sample coupled with a thorough knowledge of cropping history, sampling techniques, soil test data, environmental influences, and nutrient concentrations favour the efficient diagnosis and interpretation system (Memon et al., 2005).

\section{Conclusion}

Comprehensive review of scientific literature reveals that DRIS is a promising, effective auxiliary tool for the nutritional diagnosis in fruit crops. Except for a few studies, most of the developed research works amply clarify that DRIS is more efficient than conventional methods of nutritional diagnosis (critical values and sufficiency range) with the additional advantage of establishing a nutrient deficiency or excess ranking, according to their importance and quantifying the plant nutrient balance. The cutting edge advantage of this approach lies in its ability to minimize the effect of tissue age on diagnosis, thus enabling interested researchers to sample over a wider range of tissue age than permissible under the conventional critical value approach. Myriad of scientific groups have opined that once DRIS norms based on foliar composition has been developed for a given crop; they are universal and applicable to that particular crop grown at any place and at any stage of its development. Therefore, DRIS approach is holistic in nature, helps in identification of nutrient imbalance in crops and formulation of nutrient management strategies for achieving higher crops yields. The DRIS approach represents a step forward to strengthen our abilities to diagnose nutritional status of crops and has significant implications on nutrient management practices in horticultural and field crops. 


\section{REFERENCES}

Angeles, D. E., Sumner, M. E. and Lahav, E. (1993). Preliminary DRIS norms for banana. J. Plant Nutr., 16:1059-1070

Anjaneyulu, K. (2007). Diagnostic petiole nutrient norms and identification of yield limiting nutrients in papaya (Carica papaya) using diagnosis and recommendation integrated system. Indian J. Agric. Sci., 77: 711-714

Anjaneyulu, K. (2008). Balanced fertilization in guava using leaf nutrient standards as a guide. Abstract 47-49. In: proceedings of National seminar on policy interventions for promotion of balanced fertilization and integrated nutrient management, Krishi Vishvavidyalaya, Palampur, Himachal Pradesh, 10-11 April. Himachal Pradesh state, India.

Awasthi, R.P., Shashi, K. and Bhutani, V.R. (2000). Diagnosis and Recommendation Integrated System (DRIS) norms for peach (Prunus persics L.) in Himachal Pradesh. Indian J. Hort., 57: 277-280

Bailey, J.S., Beattie, J.A.M. and Kilpatrick, D.J. (1997). The DRIS for diagnosing the nutrient status of grassland swards I model establishment. Plant Soil, 197: 127-135

Bangroo S.A., Bhat, M.I., Tahir, Ali, Aziz, M.A, and Mushtaq, A.W. (2010). Diagnosis and recommendation integrated system (DRIS) -A Review. Int. J. Curr. Res., 10: $84-97$

Beaufils, E.R. (1971). Physiological diagnosis-a guide for improving maize production based on principles developed for rubber trees. Fert. Soc. S. Afr. J., 1:1-28

Beaufils, E.R. (1973). Diagnosis and recommendation integrated system (DRIS) a general scheme for experimentation and calibration based on principle developed from research in plant nutrition. South Africa. Soil Sci. Bull., 1: 1-132

Bhargava, B.S. (2002). Leaf analysis for nutrient diagnosis, recommendation and management in fruit crops. $J$. Indian Soc. Soil Sci., 50:362-373

Bhargava, B.S. and Raghupathi, H.B. (1995). Current status and new norms of $\mathrm{N}$ nutrition for grapevine. Indian $J$. Agric. Sci., 65: 165-169

Bhargava, B.S. and Chadha, K.L. (1993). Leaf nutrient guides for fruit crops. In: Advances in Horticulture (Fruit crops), 2. (Ed., Chadha, K.L. and Parees, O.P.), Malhotra Publishing House, New Delhi. pp 973-1030

Creste, J.E. (1996). Use of DRIS evaluation of the nutritional status of Sicilian lemon. Botucatu: Ph.D. Thesis, UNESP / FCA, 120p.

Disha, T., Rehalia, A.S. and Kumar, J. (2012). Establishment of diagnosis and recommendation integrated system norms for plum cv. Santa Rosa. Indian J. Hort., 69: 489 $-494$

Hundal, H.S., and Arora, C.L. (1996). Preliminary micronutrients foliar diagnostic norms for lychee (Litchi chinensis Sonn.). J. Indian Soc. Soil Sci., 44: 294-298

Hundal, H.S., Dhanwinder, S. and Brar, J.S. (2005). Diagnosis and recommendation integrated system for monitoring nutrient status of mango trees in sub-mountainous area of Punjab, India, Commu. Soil Sci. Plant Anal., 36: 2085-2099

Jones, C.A. (1981). Proposed modifications of the diagnosis and recommendation integrated system (DRIS) for interpreting plant analyses. Commu. Soil Sci. Plant Anal.,
12: $785-794$

Jones, J.B. (1993). Modern interpretation system for soil and plant analysis in the USA. Aust. J. Exp. Agric., 33: 1039 $-1043$

Kuldip, S., Hundal, H.S. Dhanwinder, S. and Boora, R.S. (2010). Monitoring nutrient status of ber (Zizyphus mauritiana) rruit trees in semi-arid and arid regions of Northwest India through Diagnostic Recommendation and Integrated System Approach. Commu. Soil Sci. Plant Anal., 41: 2011-2021

Letzsch, W.S. and Sumner, M.E. (1984). Effect of population size and yield level in selection of diagnosis and recommendation integrated system (DRIS) norms. Commu. Soil Sci. Plant Anal., 15: 997-1006

Meldal-Johnsen, A. and Sumner, M.E. (1980). Foliar diagnostic norms for potatoes. J. Plant Nutr., 2: 569-576

Memon, N., Memon, K.S. and Hassan, Z. (2005). Plant analysis as a diagnostic tool for evaluating nutritional requirement of banana. Inter. J. Agri. Bio., 7: 824-831

Moreno, J.J., Lucena, J.J. and Carpena, O. (1996). Effect of the iron supply on the nutrition of different citrus variety/rootstock combinations using DRIS. J. Plant Nutr., 19: 698-704

Mourao-Filho, A.A. (2004). DRIS: Concepts and applications on nutritional diagnosis in fruit crops. Sci. Agri., (Piracicaba, Brazil) 61: 550-560

Mourao-Filho, A.A., and Azevedo, J.C. (2003). DRIS norms for Valencia sweet orange on three rootstocks. Braz Agril. Res., 38: 85-93

Nachtigall, G.R. and Dechen, A.R. (2007). DRIS use on apple orchard nutritional evaluation in response to potassium fertilization, Commu. Soil Sci. Plant Anal., 38: $2557-2566$

Nayak, A.K., Sharma, D.K. Singh, C.S. Mishra, V.K. Gurbachan, S. and Anand, S. (2011). Diagnosis and recommendation integrated system approach for $\mathrm{N}, \mathrm{P}, \mathrm{K}$ and $\mathrm{Zn}$ foliar diagnostic norms for Aonla in Central IndoGangetic plains. J. Plant Nutr., 34: 547-556

Orlando, R., Eyhar, R. and Sumner, M.E. (1997). Valencia orange DRIS norms for Venezuela. Commu. Soil Sci. Plant Anal., 28:1461-1468

Payne, G.G., Rechcigl, J.E. and Stepherson, R.L. (1990). Development of diagnosis and recommendation integrated system norms for bahia grass. Agronomy J., 82: 930-934

Raghupathi, H.B. and Bhargava, B.S. (1998). Leaf and soil nutrient diagnostic norms for pomegranate. J. Indian Soc. Soil Sci., 46: 412-416

Raghupathi, H.B. and Bhargava, B.S. (1999). Comparison of CVA, DRIS and CND norms for diagnosis of nutrient balance in pomegranate. J. Indian Soc. Soil Sci., 47: 488 $-492$

Raghupathi, H.B., Sakthivel, T. and Ravishankar, H. (2013). Preliminary DRIS ratio norms for diagnosis of nutrient imbalance in Coorg mandarin. Indian J. Hort., 70:33-36

Sanchez, C.A., Sera, G.H. and Burdine, H.W. (1991). DRIS evaluation of the nutritional status of crisp head Lettuce. Hort. Sci., 26: 274-276

Santos, W.R. (1997). The evaluation of the nutritional balance of macronutrients in citrus with different fertilizations. Master Thesis. Piracicaba: USP / ESALQ, 112 p.

Savita, B. and Anjaneyulu. K. (2008). Development of leaf nutrient norms and identification of yield-limiting nutri- 
ents using DRIS in sapota cv. Kalipatti. J. Hort. Sci., 3: 136-140

Sharma, J., Shikhamany, S.D. Singh, R.H. and Raghupathi, H.B. (2005). Diagnosis of nutrient imbalance in Thomson seedless grape grafted on Dog ridge rootstock by DRIS. Coтmu. Soil Sci. Plant Anal., 36: 2823-2838

Singh, N.P., Awasthi, R.P. and Sud, A. (2000). Diagnosis and recommendation integrated system (DRIS) norms for apple (Musa paradisiaca). Indian J. Agric. Sci., 75: 432-434

Sumner, M.E. (1977). Use of DRIS system in foliar diagnosis of crops at high yield levels. Commu. Soil Sci. Plant Anal., 8: 251-268

Sumner, M.E. (1977a). Effect of corn leaf sampled on N, P, $\mathrm{K}, \mathrm{Ca}$ and $\mathrm{Mg}$ content and calculated DRIS indices. Commu. Soil Sci. Plant Anal., 8: 269-280

Sumner, M.E. (1979). Interpretation of foliar analysis for diagnostic purposes. Agron. J., 71: 343-348

Sumner, M. E. (1990). Advances in the use and application of plant analysis. Commu. Soil Sci. Plant Anal., 21:1409-1430
Sumner, M.E. and Farina, P.M. (1986). Phosphorus interactions with other nutrients and lime in field cropping systems. Adv. Soil Sci., 5: 201-236

Synder, G.H. and Kretschmer, A.E. (1988). DRIS analysis for bahia grass pastures. Proceedings of Soil \& Crop. Science Society of Florida, 47: 56-59

Szucs, E., Kallay, T. and Szenci, G. (1990). Determination of DRIS indices for apple (Malus domestica Borkh). Acta. Hort., 274: 443-453

Wairegi, L.W. and Van-Asten, P.J. (2011). Norms for multivariate diagnosis of nutrient imbalance in the East African highland bananas (Musaspp. AAA). J. Plant Nutr., 34: $1453-1472$

Walworth, J.L. and Sumner, M.E. (1987). The diagnosis and recommendation integrated system (DRIS). Adv. Soil Sci., 6: 149-187

Wortmann, C.S., Bosch, C.H. and Mukandala, L. (1994). Foliar nutrient analyses in bananas grown in the highlands of East Africa. J. Agron. Crop. Sci., 172: 223-226 